The End of Modernity 



\title{
The End of Modernity
}

What the Financial and Environmental Crisis

Is Really Telling Us

\author{
STUART SIM
}

EDINBURGH UNIVERSITY PRESS 
(C) Stuart Sim, 2010

Edinburgh University Press Ltd

22 George Square, Edinburgh

www.euppublishing.com

Typeset in 10.5/13 pt Palatino

by Servis Filmsetting Ltd, Stockport, Cheshire, and

printed and bound in Great Britain by

CPI Antony Rowe, Chippenham and Eastbourne

A CIP record for this book is available from the British Library

ISBN 9780748640355 (hardback)

The right of Stuart Sim

to be identified as author of this work

has been asserted in accordance with

the Copyright, Designs and Patents Act 1988. 